\title{
Noisy behavior of residents of an apartment building as a matter of neighborly law (the case of relationship between dog owners and neighbors)
}

Comportamiento ruidoso de los residentes de un edificio de apartamentos como una cuestión de ley de vecindad (el caso de la relación entre dueños de perros y vecinos)

\author{
Dmitry Pyatkov ${ }^{1}$ \\ Altai State University - Russia \\ pitkov@yandex.ru \\ Margarita Pyatkova ${ }^{2}$ \\ Altai State University - Russia \\ rita.piatkova@yandex.ru \\ Ulvi Amilogly Aliyev ${ }^{3}$ \\ Altai State University - Russia \\ u.aliyeff@yandex.ru \\ Polina Savitskaya ${ }^{4}$ \\ Altai State University - Russia \\ paulinass@yandex.ru
}

\begin{abstract}
The aim of this study is to examine in detail such a segment of neighborhood law as the silence related relations of neighbors in an apartment building. Neighborhood law, despite its long existence in the legal systems of foreign countries, remains unspecific in the regulation of relations between apartment owners, while in Russia neighborhood law has not received due attention from the federal legislator. We believe that competition between public and private law on this issue should be resolved in favor of private law. Civil law in the current state contains a great potential for the regulation of neighborhood relations and protection of neighborhood rights. The possibilities of civil law in this area should be expanded in the course of the forthcoming reform of property legislation. It is necessary to continue the development of neighborhood law in Russia.
\end{abstract}

Keywords: Property right, neighborhood law, ensuring silence, peace of citizens, property right reform in Russia

\section{RESUMEN}

El objetivo de este estudio es examinar en detalle un segmento de la ley del vecindario como las relaciones de vecinos relacionadas con el silencio en un edificio de apartamentos. La ley de vecindad, a pesar de su larga existencia en los sistemas legales de países extranjeros, sigue siendo inespecífica en la regulación de las relaciones entre los propietarios de apartamentos, mientras que en Rusia la ley de vecindad no ha recibido la debida atención del legislador federal. Creemos que la competencia entre el derecho público y privado en este tema debe resolverse a favor del derecho privado. La ley civil en el estado actual tiene un gran potencial para la regulación de las relaciones vecinales y la protección de los derechos vecinales. Las posibilidades del derecho civil en esta área deberían ampliarse en el curso de la próxima reforma de la legislación de propiedad. Es necesario continuar el desarrollo de la ley de vecindad en Rusia.

Palabras clave: derecho de propiedad, ley de vecindad, garantizar el silencio, paz de los ciudadanos, reforma del derecho de propiedad en Rusia

\footnotetext{
$1 \mathrm{PhD}$, Associate Professor at the Civil Law Department of the Altai State University, Law Institute, Russian Federation 2 Student of the Altai State University, Law Institute, Russian Federation

3 Graduate student at the Russian School of Private Law (Moscow), Russian Federation

4 Student of the Altai State University Law Institute, Russian Federation
}

Recibido: 04/06/2019 Aceptado: 20/08/2019 


\section{INTRODUCTION}

This article would not have been written and even its intention would not have taken place if some of the authors had not had to experience all the imperfections in the regulation of neighborhood relations. It is better to say that we have become victims of the lack of such regulation: there is no appropriate terminology in Russian law; there is no system of norms specifically designed for neighborhood relations; the principles of regulation of neighborhood relations are not formulated in the legislation and practice of its application.

The year 2017 began with the unpleasant news that neighbors living on the floor below complained to the police about the barking of our dog, accusing us of violating the city's rules for keeping pets. We were accused of not providing silence to the apartment building. The police handed over the documents to the administrative commission under the district administration of Barnaul. Because of a short investigation, the commission imposed a fine of 500 rubles based on Article 71 of the Law of Altai Krai "On Administrative Liability in the Altai Krai" (2002), i.e. for violation of municipal rules on keeping pets.

This is how we began our acquaintance with Russian neighborhood law in its public-law interpretation. Of course, we were outraged by such a verdict, appealed to the court the decision of the administrative commission, and achieved its cancellation (Decision, 2017a). However, the question remained what to do next? It was clear that the administrative commission intends to fine the owner of the dog for any noisy behavior, if one of the neighbors makes such a demand. This is how the administrative commission understood the city's rules for keeping pets: if neighbors hear your dog, you are guilty of violating the silence and should be subjected to administrative punishment. Neither the time nor the circumstances and reasons for the noisy behavior of the animal were taken into account at that time.

Possession of a dog from the point of view of the law - faultless behavior; to contain a dog in apartment - is lawful; ability and requirement of a dog to bark - the well-known fact; weak sound insulation in usual panel high-rise apartment - too the fact. However, a dog owner can be punished as many times as a neighbor can be lazy to report it. Our wallet was in the hands of our neighbors: keeping a dog threatened to become an article of endless expenses on administrative fines, for these neighbors were enough to report to the police that they hear our dog barking. It seemed to us that this state of affairs was extremely unfair: we often hear neighbors making repairs, their children playing, family scandals are also heard without much effort; why is our kind of noise so intolerable to those around us?

The unfairness of this practice was soon confirmed in the course of the analysis of the decisions of the Supreme Court of the Russian Federation. It turned out that during the last decade the Supreme Court of the Russian Federation repeatedly declared ineffective regional laws establishing administrative responsibility for any actions related to animal husbandry (Decision, 2008, 2011a, 2011b, 2012a, 2012b, 2015a, 2015b, 2017b). The position of the RF Supreme Court is that domestic animal husbandry is regulated by federal legislation and only the Russian Federation can establish responsibility for violation of these rules. For us, this approach has been life saving.

The fact is that the federal authorities have adopted numerous sanitary norms, in particular, established maximum permissible noise levels in an apartment building. These levels should be exceeded with special equipment before the owner of a dog can be punished for his noisy behavior. It is also important that the noise generated by the dog may be within acceptable limits, and therefore a simple reference to what the dog is being heard by the neighbors is not sufficient to hold the owner of the dog administratively liable.

Understanding our rightness and knowing the practice of the Supreme Court of the Russian Federation, we challenged in the Altai Krai Court of Art. 71 of the Law of Altai Krai "On Administrative Liability in the Altai Krai". The court satisfied the administrative claim, Art. 71 was found inoperative in the part that concerned us (Decision, 2017c). As expected, the Supreme Court of the Russian Federation upheld this decision (Decision, 2017d). The regional parliament was forced to obey the court decision, the legislation was amended. Now the Altai Krai Law "On Administrative Liability in the Altai Krai" has Article 61, which provides for liability for violation of silence, but with an important clarification that its effect does not apply to cases provided for by the federal legislation on administrative liability.

That is, if we take into account the reasoning part of the court decision, the owner of the dog cannot be held under this regional law to administrative responsibility for noise issued by the dog, because such relations are governed by federal legislation. In fact, it meant a stricter and fairer approach to the detection of violations and consideration of disputes; the administrative commission at the district administrations of the city are not subordinate to such cases.

It would have been easier to breathe, but it soon became clear that the practice of administrative commissions had not changed even with the new legislation, which they preferred to interpret in the old way. In 2019, we again came before the administrative commission, again challenged its resolution and received a district court decision in our favor. This time, the court did not even see the events of the offense, noting in its decision that the Law of Altai Krai "On Ensuring Silence and Quietness of Citizens in the Altai Krai" (2017) there is no administrative liability for noise produced by pets (Decision, 2019).

It cannot be said that all judges share this view of the problem. Therefore, our victory was in some sense a success; perhaps, the experience accumulated in the previous judicial battles affected us. Such a solution is not guaranteed to any dog owner.

Defending ourselves from illegal administrative prosecution all this time, we tried to present and formulate the rules of interaction of neighbors, which could be called fair. We thought about the terms of the dog owner's liability that 
we could agree to. Sincerely wondering why administrative law deals with this problem, we turned our mind to civil law in search of an answer to the question: on what legal basis should be built the relationship of the owner of the dog with his neighbors.

We did not ask civil law by chance, because it is known from the world history of law, from the history of Russian law, from the modern legislation of other countries that civil law traditionally contains a set of norms specifically designed for the relations of neighbors on various unpleasant episodes of neighborhood life. Such a set of norms is called "neighborhood law". However, in modern Russian civil law there are no such complex of norms. Its general provisions are quite applicable, but are often overshadowed and do not enjoy great popularity among neighbors, yielding competition to specific requirements of administrative legislation. The draft of large-scale changes in the legislation on property inspires hope that there will be adequate regulation of neighborhood relations in civil law, but it is only a draft, and it is not perfect (On Amendments, 2019).

Realizing that our property legislation is at an important stage of major changes, seeing and critically assessing the upcoming developments in neighborhood law, having our own experience and convictions in the courts, we have undertaken this study as a contribution to the development of the scientific basis of modern Russian neighborhood law.

\section{Aims and objectives}

The authors pursue three main goals by offering this material:

1) to show the imperfection of the neighborhood relations regulation by the norms of administrative law. Norms on administrative responsibility should not be the main regulator of relations between neighbors, their application should take place in a specific sphere for them and is conditioned by committing acts of high public danger;

2) to draw attention of participants of conflict situations to the fact that there are already adequate and even more effective means of responding to intolerable behavior of neighbors in civil law today;

3) to propose additional rules clarifying and developing the existing draft law on the reform of the Civil Code of the Russian Federation in terms of property norms and neighborhood rights.

The authors did not set themselves the task to study the problem of neighborhood law in its entirety. Based on the experience of the studied regulation of neighborhood relations, the main focus was on the problem of noisy behavior of residents in an apartment building. Such concentration of attention was also facilitated by the fact that in the abovementioned draft law the attention to neighborhood relations in an apartment building is not paid at all, we believe that this is a gap and a drawback of the project.

The noise produced by pets is obviously specific, as it comes from living creatures. Dogs are very common and yet the noisiest type of pets. This source of noise objectively cannot be under the complete control of the owner of the dog. On the other hand, noisy behavior of animals is not just an inevitable circumstance, but also even a necessary condition for their existence, including among people. The Federal Law "On Responsible Treatment of Animals and on Amendments to Certain Legislative Acts of the Russian Federation” (On Responsible, 2018) the attitude towards animals as beings capable of experiencing emotions and physical suffering is formulated as a principle (Art. 4).

Of course, emotions and sufferings can manifest themselves with noise that is not correct for the owner, especially for the animal itself. Among other principles in this Federal law the responsibility of the person for destiny of an animal, education at the population of the moral and humane attitude to animals, scientifically proved combination of moral, economic and social interests of the person, a society and the state are named. Thus, animals are a special source of noise both in their nature and in the ways of legislative regulation of relevant social relations. That is why we considered it possible in our research to identify animals among the sources of noise, and among them, we gave preference to dogs.

\section{Methods}

The theoretical basis of the research is formed by scientific publications of modern Russian and foreign authors. Largely, the research is legal in nature.

Neighborly law is restored in Russian civil law after many decades of neglect, so part of the sources - literary monuments of the Russian pre-Soviet legal thought, such as the draft Civil Code and accompanying explanations, originally published in 1910 (Civil Code, 2008).

The normative-legal basis of the research was formed by normative acts, which can be divided into three main groups: 1) federal, 2) regional, 3) foreign.

A special category of materials under study is formed by state standards, sanitary rules and regulations. In particular, they contain specific requirements to the noise level allowed in residential premises. These documents cannot be recognized as part of the civil law, they are from the field of public law, but by their content, they can become a criterion for assessing the legality of adverse impacts in neighborhood relations. As an example, the Sanitary Regulations 2.2.4/2.1.8.562-96 "Noise at the Workplaces, Residential Buildings, Public Buildings and 
Residential Areas" of 31 October 1996 can be cited (About the statement, 1996); SanPin 2.1.2.2645-10 "Sanitary and epidemiological requirements for living conditions in residential buildings and premises" (2010). Especially interesting and useful for this study is GOST R 56391-2015 "National Standard of the Russian Federation. Services for non-productive animals. Housing of non-productive animals in urban conditions. General requirements" of 20 April 2015 (Gost, 2015).

This document does not simply specify the maximum permissible noise levels, but specifically for those cases where the noise source is animals, in particular dogs.

Interest in the legislation of the constituent entities of the Russian Federation (regional acts) is conditioned by the fact that regional parliaments traditionally participate actively in the regulation of neighborhood relations. Since the Constitution of the Russian Federation (1993) does not allow the constituent entities of the Russian Federation to adopt acts containing the norms of civil law, the regional legislation on ensuring silence and peace of citizens is solely of an administrative nature.

The laws of the constituent entities of the Russian Federation on the topic of our research are very similar to each other, and very often have the same names, for example, on administrative responsibility, on ensuring silence, about keeping pets. The main objects of research from this group of sources will be the Laws of Altai Krai "On administrative responsibility for committing offenses in the territory of Altai Krai" (2002), "On ensuring the peace and quiet of citizens in the Altai Territory" (2017), "On the maintenance and protection of animals in the Altai Territory" (Animal housing, 2017).

Much attention is paid to the draft federal law № 47538-6 “On Amendments to the first, second, third and fourth parts of the Civil Code of the Russian Federation, as well as in some legislative acts of the Russian Federation" (2015). This draft law has already become a law in a significant part, but as far as property law reform is concerned, the document has no legal effect. It is in this part of the project that the norms outlining the contours of future neighborhood law in Russia are contained.

The desire to make the research practical has forced us to collect and study the practice of dispute resolution related to the noisy behavior of neighbors. The whole array of the studied jurisdictional acts can be divided into two groups: 1) decisions of administrative commissions of municipal entities; 2) decisions of courts of different levels of the judicial system.

The search for judicial practice was carried out with the help of the Garant legal reference system. At the same time, in the archive of the Leninsky District Court of Barnaul (Altai Territory), we studied the materials of the cases examined by the judges of this court for 2018 and the first half of 2019. In contrast to the materials found through the Garant legal reference system, the court's archive had the opportunity to examine the entire range of documents in each case, including complaints, petitions, and protocols, which allowed for a better understanding of the circumstances and motives of court decisions. The period since 2018 has been chosen because, since January 2018, new laws regulating the keeping of pets and establishing liability for violation of the silence and peace of citizens came into force in Altai Krai.

An important part of the materials is formed by the decisions of the administrative commission and courts in those cases in which we directly participated: the decisions of the Leninsky District Court of Barnaul dated March 30, 2017 in the case № 12-100/17; the case № 12-240/19; the decision of the Altai Territory Court № 3a-537/2017; the appeal decision of the Judicial Collegium on Administrative Cases of the Supreme Court of the Russian Federation № 51-APG17-16.

Thanks to direct participation in court proceedings, it was possible not only to create precedents that correspond to our theoretical views on the problem, but also to influence the development of regional legislation in a particular constituent entity of the Russian Federation. It can be said that the materials of these cases were not only the object of the research when writing the article, but also the result of the research in a broader sense, beyond the scope of this publication. This is a kind of a business card of our research project (Altai, 2017).

\section{Results}

In many countries, neighborhood law has traditionally been represented in the civil law system. I.A. Emelkina (2016) writes: "At present, special provisions in the civil codes of continental Europe are devoted to neighborhood law. As a rule, foreign legal orders do not contain a definition of the concept of neighborhood law.

Nevertheless, the analysis of legislation allows us to conclude that the category "neighborhood law" is considered as a set of civil law norms that establish the forms of permitted impact of the land plot owner on the neighboring land plot, its limits, the obligations of a neighbor to tolerate such impact, as well as regulate the relationship of neighbors in the event of the owner's departure from these limits, including the order and methods of protection".

This observation of the civil law nature of neighborhood law is very important from a practical point of view, as it allows the use of all civil law tools to resolve conflicts between neighbors or to establish peaceful and mutually beneficial relations between them. For example, monetary compensation can be stopped by agreement between neighbors when a neighbor allows significant influence on his or her area, as provided for in $\$ 906$ of the German Civil Code (2008). 
In Western foreign literature, there are two key concepts of "nuisance" and "neighbor law". Nuisance in Black's dictionary is a condition, activity or situation (e.g. loud noise or unpleasant smell) that interferes with the use of property (Black's Law, 2009). The Max Planck nuisance Encyclopedia also uses it as a tool for environmental protection (The Max Planck, 2017). The study of nuisance and the Human Rights Act of 1998 (Human, 2019), as well as private nuisance, belong to Donal Nolan (2011a, 2011b, 2015). Nuisance can be considered in both international (Hulsroj, 2006) and criminal law (Squires, 2008).

Nuisance is usually understood as a deliberate, unjustified, non-disturbing intrusion into the quiet use of property (Hylton, 2015). A nuisance is typically defined as an intentional, unreasonable, nontrespassory invasion of the quiet use and enjoyment of property:

The author proposes to understand by "unfounded" situations when:

(a) Existence of a high degree of interference with the quiet use and enjoyment of land of others

(b) Inability to eliminate the interference by the exercise of reasonable care

(c) Extent to which the activity is not a matter of common usage

(d) Inappropriateness of the activity to the place where it is carried on

(e) Extent to which its value to the community is outweighed by its obnoxious attributes

Professor Van der Merve described the (d) in detail (van Merve, 1998): With regard to locality, it is clear that city residents cannot expect the peace and quiet of the countryside and those dwelling in an industrial or commercial area cannot count on the tranquility of a choice residential area. In this case, the church and guesthouse are both situated in the center of town, surrounded by residences and businesses. It would thus appear that whilst the guesthouse is not entitled to the tranquility of the countryside during business hours, it could probably insist that the sleep of its clients is not to be disturbed by the unnecessary chiming of church bells throughout the night

Van der Merve interpreted the (e) as: Following locality, the benefit and utility of the activity to the landowner must be weighed against the harm suffered by the plaintiff. An interference with a neighbor's comfort will not be considered unreasonable if caused by some activity from which the landowner derives great benefit. Thus, in Glen $\mathrm{v}$ Glen proportionality is sought between the benefit derived and the harm suffered - if the interest the landowner wishes to advance is disproportionately small in comparison with the harm suffered by his neighbor, the activity will be regarded as unreasonable

A trespasser invasion is one that displaces the plaintiff from all or some portion of his property. For example, a large rock that is thrown over to the plaintiff's property displaces the plaintiff from the space in which it travels and ultimately lands. This can be contrasted with a nontrespassory invasion, such as smoke or noise, which does not displace or oust the plaintiff from any space on his property (Hylton, 2015).

Van der Merve pays special attention to the victim, the plaintiff, using an interesting example (1998): A classic application of this test is to be found in the American case of Rogers v Elliot. In this case, a person situated directly opposite a church was peculiarly susceptible to the noise caused by the ringing of a church bell to the extent that such ringing was triggering off epileptic attacks. The plaintiff failed in an action for damages against the church on the grounds that the bell was not "objectionable to persons of ordinary health and strength".

"Neighbourlaw" is translated as a neighborhood right. When talking about nuisance, we can conclude that neighbourlaw is a general concept in relation to nuisance. This can be found in the Czech Civil Code, namely in paragraph 1013. The Czech Civil Code contains the norms of neighboring law in paragraphs 1013 to 1036 (2005). It is possible to divide them according to the same system as the Code itself. In the beginning, the legislator fixes limitation of the right of ownership, then regulates elements constituting a boundary, and finishes expropriation and limitation of the right of ownership.

Paragraph 1013 interestingly defines the concept of pollution, meaning waste, water, smoke, dust, gas, smell, light, shade, noise, vibration and other similar effects. The owner should refrain from pollution if it is disproportionate to local relations and significantly limits the normal use of the land plot (Civil Code, 2005).

It is worth noting that some authors are very concerned about the excessive influence of neighborhood law on the classic right of ownership. For example, Susan Scott writes: "The treatment of encroachments in the above cases, however, is unsatisfactory in many ways, as I have indicated. Regarding their effect on ownership, they seem to indicate to an owner of land that he/she may encroach on his/her neighbor's land, provided he/she is prepared to pay compensation (including a solatium- satisfaction), almost as if it is an owner's right to do so.

Consequently, they suggest that owners are expected to endure encroachments on their land. Therefore, owners must act reasonably and accept compensation instead of relying on removal of the encroachments as of right. As a result, these judgments permit a broadening of ownership entitlements in the sense that they create the impression that the law does not really deplore encroachments (infringements) on neighboring land, and, consequently, they place a severe limitation on ownership in the sense that they create the impression that the law expects 
owners to endure encroachments by a neighboring owner. Can one really argue that this situation, which radically differs from Roman, Roman-Dutch law, and also from established South African case law, relying on English-law principles, is a wholesome development that is in line with societal needs and modern notions of ownership?" (Scott, 2017).

Usually the norms of neighborhood law in the sources we studied are addressed to the owners of land plots. At first glance, neighborhood law looks like the right of neighboring landowners. At the same time, as a rule, we are talking about problems related to water use, construction, and construction of boundary and fences. Such an emphasis on land plots is not accidental, but has a historical foundation. It is clear that the problems in the neighborhood relations are known much longer on the example of relations between landowners and not residents of a multi-store building in a metropolis.

This fact makes it difficult to use foreign legislation in our study, as we are interested in landless neighbors. Noisy neighborhood behavior is seldom mentioned in the literature we studied, even less often in the context of using residential premises in an apartment building. For example, I.A. Emelkina, referring to the work of the Austrian author Iro G., writes: "In foreign law, the limits set by local customs are also used as a criterion of exit from the permissible impact. In this case, as a rule, disputes arise in relation to the noise from cars, tennis, lawnmower operation, etc. coming from the neighboring area.

In such situations, the criterion is considered to be the relevant local rules of public order or custom (e.g., the prohibition of mowing on Sundays or evenings, rules on the possibility of playing the piano in an apartment for one or two hours a day) (Emelkina, 2016). As can be seen, noise and apartment have fallen into the sphere of neighborhood law according to local custom and are not a priority phenomenon for the basic civil legislation. This observation was quite consistent with the conclusions of I.B. Novitsky: "the colorful color of neighborhood relations, the influence on them the peculiarities of everyday life, explains the fact that in this area a rather prominent role is played not only by the local legislation (e.g., cantonal norms in Switzerland, local legislation in Germany), but also by local customs" (Novitsky, 1924).

In the history of Russian civil law, neighborhood law was presented in the form of norms regulating the participation of outsiders in the use of someone else's thing, in short - the "right to participate". Such a name of this group of norms caused censure among contemporaries. Thus, for example, G.F. Shershenevich noted that the interests of one neighbor limit the property right of another neighbor, but do not give the first an opportunity to use the property of the other, that is, the right to participate in the full sense of the word is absent: "The prohibition to attach the kitchen to the wall of another's house, to sweep away the rubbish on someone else's yard, etc.

The law calls the right to participate, while in these cases, it is undoubtedly only the constraint of the owner, but there is no participation in the use of the thing by others. (Shershenevich, 2001). That is, neighborhood rights and, for example, servitude were unreasonably merged by the legislator into one category of "participation rights".

There is a general negative assessment of the state of neighborhood law in Russia in the early twentieth century. I.B. Novitsky (1924) noted with regret that "the right of neighborhood" has the saddest fate; its study and regulation are put in the root abnormally.

Reflecting on the prospects of the development of neighborhood law in Soviet Russia, I.B. Novitsky recognized theoretical works and Western European legislation of that time as a model and reference point. That is, he saw nothing interesting in the pre-revolutionary Russian legislation on the issue of neighborhood relations. Today I.A. Emelkina comes to the same conclusion: "In the Russian legal literature of the XIX century there were no serious studies of neighborhood law. Scientific works published at that time dealt only with individual problems of legal regulation of relations between neighbors. Partly such a situation can be argued by the fact that the understanding of the institution of neighborhood law may well have occurred later, but with the well-known political events of the beginning of the last century, this topic was unclaimed" (Emelkina, 2016).

Possible comprehension of the institution of neighborhood law is associated with the long-term development of the draft Civil Code in pre-revolutionary Russia, where the norms of neighborhood law were kept in a systematic form in large numbers and were created taking into account the examples of European jurisprudence of that time. It was not possible to rise to a higher level of neighborhood law because of the revolutionary events of 1917, which stopped working on the project.

In Soviet times, neighborhood law was not developed. I.A. Emelkina and Y.D. Subaeva write in this regard: "With the liquidation of private land ownership in the last century in the Soviet state, the norms of neighborhood law were transferred to the category of public-law regulation (legislation on urban and rural development, environmental protection, etc.).

Civil legislation established only general provisions on the exercise of property rights, its limits and boundaries" (Emelkina, Syubaeva, 2017). Similarly, the issue of regulating neighborhood relations in the housing sector, in particular, relations between residents in an apartment building, was resolved. Private ownership of residential premises was not liquidated, but urban development was dominated by public housing. Special attention should be paid to this. This may explain the widespread procedure of bringing to administrative responsibility dog owners who violate regional legislation on silence, which again has an administrative and legal nature. 
In modern Russian civil law, the norms of neighborhood law are not codified in any noticeable way.

Therefore, the legal basis for the regulation of neighborhood relations and conflict resolution between neighbors can be only the most general provisions of civil law: on the limits of civil rights, on integrity, on property, on methods of protection of civil rights, in particular on a negative claim, on compensation for moral damage. There is a theoretical understanding of the problems of neighborhood law.

The articles and monographs of modern authors cover the experience of other countries, pay attention to the pre-revolutionary experience of regulation and study of neighborhood relations, and give a critical analysis of the project of upcoming changes in property legislation. Unfortunately, the problem of noisy behavior of neighbors in an apartment building, which is of interest to us and is connected with such a specific source of noise as a dog, is almost ignored, except for rare articles specifically devoted to this problem (Tlesarev, 2016).

Neighboring law is often considered in the context of restricting property rights. This is correct, but of greater interest is another term, which is unusual for Russian jurisprudence - "patience". It is also found among domestic and foreign authors, in the current acts of foreign legislation and in the draft federal law № 47538-6 "On Amendments to the first, second, third and fourth parts of the Civil Code of the Russian Federation, as well as in some legislative acts of the Russian Federation. Here are some examples (the word "tolerate" is highlighted everywhere by us).

G.F. Shershenevich (2001) wrote about the reasons for the legislator to restrict the right of ownership: "Such restrictions consist of either a) the obligation of the owner not to do anything from what he could do in terms of the content of the right of ownership, or b) the obligation to tolerate something from others, which he could not allow in terms of the content of the right of ownership".

Article 787 of the draft Civil Code of the Russian Empire proposed a rule that the owner of the downstream estate should tolerate natural water runoff from the upstream estate and has no right to construct any structures that would prevent this runoff or change its natural direction to the detriment of neighboring changes (Civil Code, 2008).

I.B. Novitsky (1924b) characterized one of the directions of regulation of neighborhood relations as follows: "it is established to what extent one neighbor has the right to invade positively the sphere of another neighbor so that the latter is obliged to tolerate this positive impact". I.A. Emelkina (2016) quotes the following words of German lawyer O. Girke: "Neighborhood law establishes restrictions by virtue of which the owner is obliged either to refrain from certain use of his land plot or must tolerate the actions of another person - a neighbor in respect of the land plot that is in his ownership".

I.A. Emelkina writes: "In the case of a neighbor's exit from the permissible impact of the norms of neighborhood law are aimed at achieving two objectives: to settle the conflict through a private law agreement, including the condition of monetary compensation for damages and the obligation to endure the impact without applying for judicial protection, in the case of failure to reach an agreement - to provide protection of the rights of a neighbor in an administrative or judicial order".

When we say that the norms of neighborhood law are not codified in any visible way in Russia, we mean the civil legislation. Nevertheless, as has already been noted, the regulation of neighborhood relations is actively engaged in public law. Of course, neighborhood relations for public law are not always the main object of regulation. It looks at them through the prism of public interests.

Nevertheless, it is in public law that we find norms that are most specialized in cases of violation of silence in an apartment building by owners of pets, in particular dogs. Federal legislation generally contains general rules on adverse effects on the neighbor, often these rules are so general that they are applicable to any situation of adverse effects, not necessarily related to neighborhood relations. For example, there is an obligation to comply with noise limits in residential areas, these limits are set for daytime and nighttime and administrative liability for violations of these rules is established.

While modern Russian housing legislation only defines in the most general way the duty of homeowners to take care of the interests of their neighbors, in Soviet-era regulations, which are still in force, it is possible to find the most specific rules of conduct for dog owners: to take measures to ensure silence in the living quarters; when dogs are outdoors at other times, their owners should take measures to ensure silence. However, unlike the general requirements to comply with noise limits, this silence requirement is not specifically sanctioned.

Seeing the lack of attention on the part of the federal legislator to the problem of keeping pets in cities, the authorities of constituent entities of the Russian Federation and municipal formations began to get involved in the regulation of such relations. They believe that there is a gap in the federal legislation, and since the keeping of pets is the sphere of administrative law, the subjects of the Russian Federation and municipal entities are able to fill the gap with their acts.

This is the most vulnerable place in the system of legislation regulating the keeping of pets in residential premises. Is there really a gap in the federal legislation? Can the legislative bodies of the constituent entities of the Russian Federation establish rules for keeping pets and administrative responsibility for their violation? 
The regional authorities answer both questions in the affirmative, which has resulted in the adoption of laws on domestic animal husbandry, silence and peace of mind by regional parliaments. However, there is another point of view: the existing sanitary and veterinary legislation of the Russian Federation makes regional regulations on this issue superfluous and does not allow establishing administrative responsibility of the owner of a dog for its barking or other noisy behavior at the level of a subject of the Russian Federation.

Regional legislator, establishing administrative responsibility for violation of the rules of keeping pets, invades the competence of the Russian Federation in the field of legislation on administrative violations, because the qualification of this offense is not excluded under Article 6.3 of the Code of Administrative Offences of the Russian Federation (Code, 2018) (violation of legislation in the field of sanitary and epidemiological well-being) or Article 6.4 of the same Code (violation of sanitary and epidemiological requirements for the operation of residential premises Violation of the rules of keeping pets is a special case of violation of the legislation on veterinary medicine, on sanitary-epidemiological well-being of the population, that is, not some new kind of illegal activity, but a special case of violation of existing federal legislation, which is very extensive.

As noted in the definition of the Supreme Court of the Russian Federation № 81-APG12-1 (Decision, 2012a), the welfare of the population - it is not only the health of the population, but also the welfare of the human environment, in which there is no harmful impact of environmental factors on the person and provided favorable conditions for his life (Art. 1 of the Federal Law "On Sanitary and Epidemiological Welfare of the Population" (1999).

Therefore, the legislation on sanitary-epidemiological well-being of the population is the basis for the approval of sanitary standards 2.2.4/2.1.8.562-96 "Noise at the workplace, in the premises of residential, public buildings and on the territory of residential development" (approved by the resolution of the State Committee for Sanitary and Epidemiological Surveillance of the Russian Federation No. 36 and sanitary-epidemiological rules and standards of SanPiN 2.1.2.2645-10 "Sanitary-epidemiological requirements for living conditions in residential buildings and premises" (approved by the Resolution of the Chief State Sanitary Inspector of the Russian Federation No. 64).

These normative legal acts establish the permissible noise level in residential premises for day and night time. GOST R 56391-2015 "National Standard of the Russian Federation evidences the fact that the noise level requirements established by the federal government body are directly related to the maintenance of pets. Services for non-productive animals. Housing of non-productive animals in urban areas. General requirements" (approved by Rosstandart Order No. 268).

Paragraph 10.3 of the National Standard specifies the permissible noise level for day and night among the physical parameters to be monitored in order to determine the impact of the animal on the environment, specifying that it may be screams, barks, howls, blows, etc. The physical noise values provided for in the National Standard comply with CH 2.2.4/2.1.8.562-96 and SanPiN 2.1.2.2645-10.

According to Article 56 of the Federal Law “On Environmental Protection” (2002) all entities, when carrying out economic and other activities, are obliged to take necessary measures to prevent and eliminate the negative impact of noise, vibration and other physical impact on the environment in urban and rural settlements.

This norm is another proof of the statement that the problem of negative impact of noise on people, regardless of the source of noise, including the noisy behavior of pets, is the subject of concern of the federal legislator. He also establishes responsibility for violation of the noise limit as a violation of legislation in the field of sanitaryepidemiological well-being (Art. 6.3 of the Code of Administrative Offences) or sanitary-epidemiological requirements for the operation of residential and public premises, buildings, structures and transport (Art. 6.4 of the Code of Administrative Offences). The legislation of the subject of the Russian Federation concerning in any degree these questions, will at the best duplicate the federal legislation, in the worst case - to contradict to it.

However, not all regional laws have been judicially checked for compliance with the Constitution of the Russian Federation and federal legislation. Courts of lower levels of the judicial system are forced to work in conditions when regional normative acts contradicting the federal legislation, but not recognized as inoperative, may be in force on the territory of a constituent entity of the Russian Federation.

We faced such a state of affairs in 2017, appealing for the first time an illegal decision of the administrative commission to impose a fine for barking a dog. We tried to prove at the meeting of the commission, in court that the law of Altai Krai applied in our case is contrary to federal law, and should not be applied. The administrative fine established by him should not be levied on us. We demanded that our conduct be assessed in terms of federal law. It was clear to all of us that as long as the rule of Altai Krai law applied in our case was not declared inoperative; there would still be a threat of its application in such cases.

This prompted us to apply to the court with a demand to invalidate the rule of the regional law, which establishes, in particular, responsibility for barking dogs. Our demand has been satisfied, the norm has lost its force, it has been cancelled, now in Altai Krai there is other legislation in force.

The court practice in cases of noisy behavior of dogs is contradictory not only because the courts in the constituent entities of the Russian Federation apply different regional legislation in terms of quality. Even if the law on liability 
for noisy dog behavior is applied, its effect can be significantly adjusted through the application of sanitary norms established by federal authorities. In particular, it is possible to take into account the maximum permissible level of noise, which is fixed in the sanitary norms.

Nevertheless, in practice there are different approaches to the use of these standards: someone is ready to use special devices to measure the level of noise emitted by the dog to bring a neighbor to justice; others believe that these standards are addressed to enterprises and organizations that can adversely affect the situation in the residential area. Such different opinions are held not only by ordinary citizens, but also by judges and administrative officials. When the maximum permissible level of noise is not taken into account, the risk of being prosecuted increases significantly, it becomes almost inevitable: it is enough for the neighbor to hear the dog and have a desire to complain to the police.

However, the most interesting aspect of court practice is competition between civil and administrative law. While the administrative law assumes the function of a regulator of the behavior of dog owners in an apartment building, the civil law can compete with it through its general provisions. Neighborhood relations are not excluded from their scope, and protection of neighbors' rights can be considered as a special case of civil rights protection. In practice, there are many civil disputes between neighbors about the noisy behavior of a dog. Sometimes a civil suit is brought after unsuccessful attempts to change the neighbor's behavior at the expense of administrative procedures. A civil lawsuit can be brought immediately if the plaintiff sees no point in administrative punishment of a neighbor.

Below are some of the most interesting examples from the court practice, which will show a rich palette of life situations associated with noisy behavior of dogs in an apartment building.

To begin with, let us consider examples of attraction of the citizens owning dogs, to administrative responsibility for infringement of silence and rest of neighbors in an apartment house. The main part of the examples will be made up of the cases we studied in the archive of the Leninsky district court of Barnaul. In all cases, the owners of dogs appealed in court against the decision of the administrative commission to impose a fine on them. Cases were considered by different judges, making different decisions and arguing them differently.

Example 1: Case of P.Y. and P.I. (These people live together and keep a common Yorkshire terrier, were brought to responsibility separately on the complaint of the same neighbor).

Decision of the Leninsky District Court of Barnaul of 1 April 2019 in case \#12-123/2019 (Decision, 2019a).

P.Y., as the owner of a dog violating the silence and peace of citizens, was subjected to administrative punishment in the form of a fine of 600 rubles. P.Y. did not agree with the decision of the administrative commission and filed a complaint with the court with the request to cancel the decision and terminate the proceedings. In P.Y.'s opinion, the barking of the dog does not depend on the will of the person, which means that there is no event of violation in the case. In addition, P.Y. was not in the apartment during the barking of the dog, so she could not take any measures. P.Y.Y. also refers to the norms of law establishing permissible noise levels in residential premises. In the case of their excess was not proved. The court satisfied P.Y.'s complaint and agreed that in this situation there was no event of an administrative offence: since P.Y. was absent from the apartment during the period of the dog's noisy behavior, he could not be a violator of citizens' silence and peace. She was not charged with any other offence (violation of the rules of keeping pets). P.Y. was released from responsibility.

Decision of the Leninsky District Court of Barnaul dated 3 April 2019 in case No. 12-122/2019 (Decision, 2019b).

P.I. was also punished by a decision of the administrative commission in the form of a fine of 500 RUR for violations of silence and peace of citizens. P.I. did not agree with the decision and appealed to the court, used the same arguments as in the case of P.I. According to the court decision, the administrative commission had initially mischaracterized the actions of P.I. In this case, there was a violation of not the legislation of the Altai Territory on silence, but of the rules of keeping pets, according to which the owner of the animal must provide silence and peace for others. This offence was not charged by P.I. During the period of noisy behavior of the dog on the night of December 14-15, 2018. P.I. was not at home and could not disturb the silence and peace of his neighbors. In his actions, there was no composition of such administrative offence as violation of silence and rest of citizens. The court satisfied P.I.'s complaint.

Decision of the Leninsky District Court of Barnaul of 7 May 2019 in case \#12-121/2019 (Decision, 2019 c).

P.I. is subjected to administrative punishment for the second time as the owner of a dog violating the silence and peace of citizens. He is sentenced to 600 RUR. P.I. did not agree with the decision of the administrative commission and filed a complaint with the court with the request to cancel the decision and terminate the proceedings. P.I. used the same arguments as in his previous complaints and drew attention to the fact that the norms of the Altai Krai legislation, which he allegedly violated, duplicated the federal legislation. In other words, the Altai Krai legislation on administrative responsibility for violation of the silence and peace of its citizens creates competition with the federal legislation and exceeds its powers. The court did not release P.I. from responsibility and upheld the decision of the administrative commission, but reduced the amount of the fine to 500 rubles. In the court's opinion, the noise level was of no legal significance, and the testimony of the victim and witnesses was sufficient evidence of P.I.'s guilt: he allowed the barking of a dog between 13.15 and 13.45, i.e. he did not take measures to 
ensure the silence of the pet in the living quarters.

\section{Decision of the Leninsky District Court of Barnaul dated 28 June 2019 in Case 2-218/2019 (Decision, 2019d).}

P.I. again found himself in the situation described above. The administrative commission imposed a fine of 1300 rubles. P.I. did not agree with the decision and appealed to the court with a complaint and request to cancel the decision. The same arguments were used as in the previous complaints. The court's decision in this case turned out to be similar to the decision in case No. 12-121/2019. The court changed the decision, imposing a fine of Br500, and the complaint was not satisfied.

Example 2: Case of P.G. (We were directly involved in this case. It is a part of a set of legal materials, which in section 3 "Materials and methods" we called the hallmark of our project)

\section{Decision of the Leninsky District Court of Barnaul of 20 June 2019 in case \# 12-240/2019 (Decision, 2019a).}

P.G. was brought to administrative responsibility for allowing a barking dog to bark during the daytime from 13.00 to 15.00 (at this time, as well as at night, a particularly strict observance of silence is required in the Altai Territory), thus disturbing the silence and peace of the neighbors living on the lower floor. P.G. was prosecuted under Altai Krai law, as were other citizens in the cases described above. P.G. filed a complaint with the court against the administrative commission's decision and asked for its cancellation. The main argument of the complaint was that the law of Altai Krai on silence and peace of citizens does not apply to the case of violation of the silence of barking dogs. In general, the legislation of Altai Krai does not apply to neighboring relations related to animals. In the case, federal administrative legislation should be applied, in particular the Code of Administrative Offences of the Russian Federation, but there is no evidence of violation of federal legislation, such an offence was not imputed to P.G. Application of federal legislation means, in particular, the need to measure and take into account the level of noise emitted by the dog.

That is, not any noise is sufficient to bring the owner of the dog to administrative responsibility. In substantiation of her complaint, P.G. referred to the decisions of the Altai Territory Court and the Supreme Court of the Russian Federation, made in her case in connection with the challenge of the Law of Altai Territory "On Administrative Liability for offenses in the territory of the Altai Territory", which recognized that the relationship on the maintenance of pets is regulated by federal legislation and the Altai Territory has no right to establish administrative liability for violations of the rules of keeping pets.

The court satisfied the complaint of P.G. and released it from administrative responsibility, because in its actions there is no event of administrative offense: the Law of Altai Krai from December 6, 2017 № 95- "On ensuring the silence and peace of citizens in the territory of the Altai Krai" in the case of P.G. cannot be applied, it does not concern the cases of violation of the silence of pets, and other misdemeanors she was not imputed.

Example 3. Case of G.P. (About seven Amertoys. The decision is taken from the reference legal system Garant, its date is not known to us).

The decision of the Tchaikovsky City Court of the Perm Territory in case No. 12-342/12 (Decision, 2019e).

The resolution of the magistrate's judge G.P. was found guilty of committing an administrative offense under part 1 of article 2.8 of the Law of the Perm Krai "On Administrative Offences" and he was sentenced in the form of an administrative fine for the fact that he, being the owner of seven Amertoy dogs, did not provide their proper maintenance in the apartment: on the night of the dog barking, thereby violating the silence and peace of the neighbors.

G.P. filed a complaint to the court requesting the magistrate's court to cancel the decision, in the absence of an administrative offence, referring to the fact that the legislation establishes maximum permissible levels of noise during the day and night in residential premises and measures them in accordance with the Sanitary Norms of permissible noise in residential and public buildings and residential areas.

In order to accuse someone of having committed an administrative offence of exceeding the maximum permissible noise level, the noise emitted had to be measured, and a corresponding act had to be drawn up from which it had to be seen what level of noise came from pets. There is no such evidence in the administrative case.

The court did not satisfy the complaint, and in the opinion of the court, the complaint's argument that there was no act of noise measurement in the case could not serve as a basis for G.P.'s exemption from liability.

Now let us consider civil-law disputes of neighbors caused by noisy behavior of dogs.

Example 1. The case of dog flocks in an apartment (ban the maintenance) (Decision, 2016).

In the Sverdlovsk region, the case of mass keeping of dogs in an apartment was considered. The plaintiffs applied to the court with a request to ban the defendant from keeping dogs. In support of their claims, they explained that the defendant kept a large number of dogs in his apartment. They suffocate from an unpleasant smell. There 
is a dog howl in her apartment that prevents them from resting. There are puppies now. At the same time, the defendant was repeatedly brought to administrative responsibility under Article 37 of the Law of the Sverdlovsk Region "On Administrative Offences in the Territory of the Sverdlovsk Region". The police officers repeatedly held preventive talks with him about the inadmissibility of keeping a large number of dogs in the apartment.

The court satisfied the plaintiff's demands and ordered him to release the apartment from animals with a ban on further keeping of dogs in the apartment. In the opinion of the court, the defendant's failure to comply with the court's earlier decision, the continuation of illegal actions, which are reflected in the violation of the plaintiffs' housing rights for a long time, antisocial behavior, consisting in ignoring the rights of neighbors, is regarded by the court as an abuse of rights.

The maintenance of a large number of dogs in the apartment itself entails the impossibility of full control over the processes of animal life, affects the interests of other persons. At the same time, unsanitary conditions are created; the level of noise is increased, which violates the right of neighbors to a favorable environment.

\section{Example 2: The case of dog flocks in an apartment (reduce the number of dogs) (Decision, 2014).}

The Nagatinsky District Court of Moscow considered the case. In this case, the plaintiffs also demanded a ban on keeping pets. In support of their claims, they explained that the defendant kept a large number of large breeds of dogs in his apartment. He walks the dogs without muzzles. Dogs constantly barking, whining, scratching floors, walls, and doors in the common corridor, do not give rest to tenants day and night.

The defendant does not watch his animals, does not clean them up, the smell of stink comes out of the apartment, cockroaches spread, and the entrance to the house is dirty. From the plaintiff's explanations it follows that the defendant Moiseeva's keeping the dogs is exceeding the permissible level of noise in the house at night, which violates the rules of living together and the rights of the residents of the house, and the violation of hygienic rules poses a threat to the physical health of persons living in the entrance.

In support of this, the plaintiffs presented the result of acoustic measurements made by the testing laboratory: the noise level in the period when the barking of dogs is heard does not meet sanitary standards. During the consideration of the case, a forensic sanitary-epidemiological examination of the noise level measurement was appointed and conducted. The experts concluded that the noise produced by pets at night exceeded the maximum permissible level defined by the normative and technical documents.

The court decided that animal husbandry should be limited to two dogs.

\section{Example 3. The case of an elderly poodle (Decision, 2015c).}

The plaintiff appealed to the Sverdlovsk District Court of the city of Perm with a request to impose a ban on the defendant's dog maintenance. The claimant offered to transfer the dog to the local public organization of animal protectors. He demanded compensation for the moral damage caused to him. According to the plaintiff, the defendant contains an elderly dog, which he never walks, keeps only in a closed room; the staircase is spread on the smell of rotten smell, thus creating unbearable conditions for living. In addition, their peace for six months violates the barking and howling of the animal, which comes from the neighbor's apartment almost all day long. In some hours, the dog howls most actively. The plaintiff repeatedly appealed to law enforcement agencies and local authorities, but no violations by the defendant were found. Some witnesses heard the dog's noisy behavior and confirmed it.

The court refused to satisfy the claim, as the plaintiff did not prove and the court did not find any violation of sanitary, epidemiological, and veterinary-sanitary rules. Nevertheless, the court satisfied the claims for compensation of moral damage.

\section{Example 4. The case of a noisy badger-dog (Decision, 2017e).}

The Kalininsky District Court of Ufa also considered the case, where the subject of the dispute was noise from one of the neighbors' pets. The plaintiffs explained that the defendant was holding a badger-dog. The dog barks during the whole day when one of them stays in the apartment, and other neighbors confirm the continuous barking. Dog barking does not give the plaintiffs the opportunity to stay calm in their own apartment, which violates their rights as owners of residential premises. The fact of violation of rights is confirmed, in respect of the defendant is drawn up an administrative protocol. In this regard, the plaintiffs ask to oblige the defendant to eliminate the above violation, to recover from the defendant monetary compensation for moral damage.

The court refused to satisfy the claim, as the plaintiffs did not submit any evidence to the court to confirm their arguments. The court explained that the barking of the dog must exceed a certain level of noise. It is impossible for the court to determine how loudly and for how long the dog barks. It is only possible to determine the noise level by carrying out an expertise in an apartment. However, the parties did not declare it in court.

\section{Example 5. The Rhodesian Ridgeback case (Decision, 2017f).}

The Mozhaisk City Court prohibited local residents from keeping their own dog in the apartment. According to 
the plaintiffs, the neighbor's Rhodesian Ridgeback constantly howls when the owners are not at home. According to the residents, their quiet life ended in 2014, when neighbors started holding Ridgeback. As soon as the owners left the house, the dog began to howl desperately. Discomfort, according to the plaintiffs, is not the power of sound, but the way the neighbors' pets howl.

The plaintiffs and other neighbors repeatedly appealed to the police, administrative and technical supervision and municipal authorities. These bodies carried out checks, during which the howling of the defendants' dogs at night was confirmed, but the defendants were not brought to administrative responsibility, as the local legislation does not have a norm of law allowing to bring to administrative responsibility for violation of silence.

The court concluded that the defendants, through their actions related to the inadequate maintenance of their dog, violated the rights of the plaintiff as the owner of the dwelling and satisfied the claim.

\section{Discussion}

It is important to recognize neighborhood law as an element of the civil law system. Administrative-legal bias in the regulation of neighborhood relations in modern Russia has reasons that are noticeable in historical retrospect. These reasons - the abolition of private ownership of land - and in Soviet times, not all experts were recognized as sufficient to reject the neighbor's civil law, and in the modern conditions and have no action at all. There are all grounds to revise the current situation in favor of civil law regulation of neighborhood relations. In any case, civil law should become the main regulator of this sphere of public life. It is impossible to recognize the correct situation when civil law and administrative law compete on the issue of responsibility for noisy behavior of pets.

Administrative law is not effective in this case for a number of reasons. Barking, howling, and squealing of a dog in a dwelling cannot be called a socially dangerous behavior of a dog owner. It does not have the degree of danger when it would be necessary to use the arsenal of administrative law.

Y.M. Kozlov (1999) writes: “...public danger is also a sign of administrative offense, an expression of its illegality. Otherwise, it is difficult to explain why the state uses its power to combat such acts and widely applies legal means of coercion, if these acts do not pose any danger to the interests of society. Sometimes administrative offences are called anti-social, which is also in line with their public danger.... Of course, they are also harmful".

Y.A. Tikhomirov (2001). uses another definition: "An administrative offence (misdemeanor) is an infringing on the state or public order, property, rights and freedoms of citizens, on the established order of management illegal, guilty (intentional or careless) action or omission, for which the legislation provides administrative responsibility".

Can we assert that violation of silence by a resident of an apartment building is a dangerous act for the society? Rather, such behavior can be considered dangerous or, rather, uncomfortable for individuals. In connection with the above, it seems obvious to us that such relations should not be regulated by the norms of administrative law and this is confirmed, among other things, by the theoretical basis of administrative law.

We can allow the idea of administrative responsibility for the dog's walking in an undisclosed place, without a leash or muzzle. It is connected with danger for the uncertain circle of the person. On the contrary, the noisy behavior of a dog, as practice shows, is localized. Events take place in a separate apartment, belonging to the owner of the apartment, and affect the interests of the nearest neighbors. Often in the materials of court cases, there is information that complaints about noisy behavior of the dog come to the law enforcement bodies against the background of unpleasant relations between neighbors, which can be caused by quite different reasons.

Y.M. Kozlov writes about administrative law in the following way: "Administrative law is a set of legal norms with the help of which the state regulates public relations arising in connection with and concerning practical realization of executive power... we mean only those relations in which this or that executive body, i.e. the corresponding subject of executive power, necessarily participates. Without their participation, public relations go beyond the framework of administrative-legal regulation.

These are, for example, relations between citizens, between public associations and within them, relations between industrial enterprises, commercial structures based on economic and contractual principles, etc." (Kozlov, 1999). Similar reasoning can be found in the work of Yu.A. Tikhomirov (2001): "Thus, public interests, secured by administrative law, acquire the meaning of normative guidelines of activity and criteria for the adoption of legal acts and other documents.

They contribute to the formation of socially significant legal consciousness of citizens and motivation of their behavior, prevent deviations from the general rules and hypertrophy of private, personal interests. Namely, this trend of Russian reality is very painfully reflected in different spheres of state and public life". That is, researchers specifically emphasize that private interests of citizens and their relations with each other should not fall into the sphere of regulation of administrative law. We find in this confirmation of our point of view.

In a year and a half, eight cases were considered in the Leninsky District Court of Barnaul to appeal against the decisions of the administrative commission to bring to justice the violators of silence. Six of them were about the noise of pets. It is not that the violators of silence agree with the decisions of the administrative commission and 
do not seek to challenge them in court. There are few cases in the administrative commissions themselves.

Most of the cases we studied in the Leninsky District Court of Barnaul are complaints of the same persons. The small number of cases and the repetition of participants in them speaks more about the importance of silence and its observance for individuals, rather than about the public importance of such cases. This also confirms the disinterest of neighboring witnesses in participating in the hearing (in one case, the witness had to be forcibly brought before the court to testify against the violator of silence). The cases of violation of silence are connected with extreme subjectivism. On the one hand, people may perceive noise differently and react to it, but on the other hand, neighbors may use the "flexibility" of silence legislation to settle personal scores with each other.

Penalties for administrative law have little effect on the behavior of the dog owner, who already tends to take measures to reduce the noise emitted by the animal. However, the animal is susceptible to a fine. Administrative punishment does not solve the main problem - it does not eliminate the source of trouble for neighbors.

Thus, it can be concluded that the existing way of solving such disputes by means of public law is unproductive. Meanwhile, effective means of resolving disputes between neighbors can be found in civil law. A nigger lawsuit, if granted, can solve the main problem - to eliminate the source of noise and discomfort or to significantly reduce the adverse impact on neighbors. Practice shows that the traditional civil remedy is universal and flexible enough to become a means of regulating neighborhood relations.

The satisfaction of a negative claim should not necessarily have the effect of prohibiting the keeping of a pet. In some cases, it is sufficient to reduce the number of dogs or to impose additional obligations on the owner of the dog, which will reduce the noise level. For example, a court may order the owner to strengthen the soundproofing of the room. It is possible that, given the circumstances of the case and the position of the defendant, such a duty of soundproofing will be imposed on both sides of the process in equal or different proportions.

Another specific way of resolving a dispute may be to impose on the owner of the animal the duty of enhanced supervision of the animal. It may be like inviting a care to a person when the owner is absent for a long time or the animal is ill, has special character traits and requires constant contact with people. In the cases we studied, there were suggestions of neighbors to take part in watching a noisy dog, which wails and barks particularly hard when it is left alone.

This kind of cooperation between neighbors to ensure peace and quiet in the house can also be one of the options for resolving the dispute, if the circumstances of the case and the position of the parties are conducive to it. Other examples of solving the problem without removing the dog from the premises (medical intervention, use of special technical means) could also be given.

Currently, we do not see anything like this in the general property provisions, in the negatory lawsuit. The application of these rules is possible already now and happens in practice, but the development of neighborhood law should follow the path of specialization of general property provisions indicating the specific ways of dispute resolution.

The newest norms of mandatory law, in particular, the amendments adopted in 2015 on the so-called astronauts, can provide significant assistance in ensuring the enforcement of judicial decisions in neighborhood disputes. According to Article 308.3 of the Civil Code of the Russian Federation (2005), in the event of default by the debtor of the obligation, the creditor has the right to demand the execution of the obligation in kind by court, unless otherwise provided by this Civil Code of the Russian Federation, other laws or the contract, or does not arise from the essence of the obligation.

The court, at the creditor's request, has the right to award in its favor a sum of money in the event of nonfulfillment of the said judicial act in the amount determined by the court based on the principles of fairness, proportionality and inadmissibility of deriving benefits from illegal or unfair conduct. Thus, civil law has its own monetary mechanism for influencing the silent violator, who ignores the interests of neighbors and does not rush to comply with the court's decision, which, as we have found out, can be most accurately selected for any specific situation.

This monetary mechanism has three advantages over an administrative fine: 1) the amount is determined by the court in the light of the circumstances of the case and may be much more sensitive to the silent offender, 2) it may be recovered repeatedly before the execution of the court decision without careful preliminary judicial proceedings, 3 ) it is recovered in favor of the neighbors and not the state, thus compensating them for the continuing troubles.

We regret that the long-prepared amendments to the Civil Code of the Russian Federation, the adoption of which should restore full neighborhood law in Russia, are almost entirely devoted to the neighborhood relations of landowners. It seems that the developers of the amendments do not know that in the cities people are also in neighborhood relations, even closer than the landowners are. This is an obvious drawback of the bill.

The development of civil law regulation of neighborhood relations should not exclude cooperation between civil law and public law. We believe that the issue of applying sanitary norms to the neighborhood relations, which has been repeatedly raised in practice, should be resolved positively. That is, the maximum permissible noise level defined in sanitary rules should be taken into account when settling civil law disputes. This should not lead to 
formalism, and other ways of determining the degree of adverse impact of one neighbor on another are not excluded.

However, the professional measurement of noise level should be taken into account first. Otherwise, neighbors are in a worse position than other violators are of silence, such as industry, entertainment and similar organizations. They have the right to create any trouble for the residents of apartment buildings within the limits of the norms established by the state. It goes without saying that the legislation on enforcement proceedings, as well as the method of work of bailiffs should be improved taking into account the development of the neighbor's law.

\section{CONCLUSIONS}

Neighborhood relations are by their very nature subject to civil law norms. Civil law should become the main regulator of this sphere of public life. This conclusion concerns neighborhood relations not only in the sphere of land use, but also in apartment buildings. The formation of neighborhood law is in demand by the practice of public life.

Subjects of the Russian Federation should not take an active part in the regulation of neighborhood relations, since the civil legislation is the subject of exclusive jurisdiction of the Russian Federation. At present, neighborhood relations, in particular related to ensuring silence and peace of citizens, responsibility for violations in this area, are fully regulated by federal administrative legislation, which again excludes the subjects of the Russian Federation and municipalities from the number of law-making instances.

We have considered expediency of solving neighborhood conflicts on the issue of violation of silence with the help of methods of administrative law. The practice as a whole and our own analysis of court cases testify to the inefficiency of these methods. Civil law even in the modern state contains a great potential for regulation of neighborhood relations and protection of neighborhood rights. The possibilities of civil law can be expanded in the course of the forthcoming reform of property legislation.

Critically estimating the project of the federal law No. 47538-6 "About modification of a part of the first, second, third and fourth Civil code of the Russian Federation, and also in separate acts of the Russian Federation", we suggest to the legislator at formation of the neighboring right not to be limited by relations between owners of the ground areas and to pay attention to relations in apartment houses.

The peculiarity of neighborhood relations in apartment buildings and specificity of conflict situations are conditioned by specific sources of trouble for neighbors, in particular, by noisy behavior of residents. Conflicts related to the keeping of pets, such as dogs, in apartments have become widespread. Animals often become a source of unpleasant smells and sounds, and for other reasons can cause unpleasant attitude to the owners from neighbors.

In regulating this relationship and in resolving disputes, it is necessary to take into account the peculiarities of animals as sources of unpleasant impact on neighbors: they are not fully under human control, such as musical instruments, equipment, etc. They are capable of emotions, fear and pain. For this reason, animal noise cannot be as judgmental as shouting, listening to music at high volume, playing instruments and singing.

Today, there is a widespread misconception in society of silence as a good thing. Many people tend to view silence and the right to silence as an unconditional benefit, without paying attention to the fact that for other people living in the neighborhood, the greatest benefit is a normal human life, one of the manifestations of which can be noise, for example, from a beloved family friend with four legs.

Unfortunately, the regional legislation reinforces this misunderstanding by ordering the residents of apartment buildings to remain silent at a certain time, giving the citizens hope that it is possible to compel the neighbors to behave in such a way that they are not heard at all. However, silence as a complete absence of sounds is an unattainable luxury in modern urban life, especially in apartment buildings with poor sound insulation.

Neighborhood law is designed to offer people the idea of compromise and some specific options. For this reason, one can only welcome the appearance of the term "patience" in Article 293 of the draft Federal Law No. 47538-6 "On Amendments to Parts One, Two, Three and Four of the Civil Code of the Russian Federation, as well as to Certain Legislative Acts of the Russian Federation”, which describes one of the obligations of the owner: "The owner of the land plot must undergo the impact of gases, vapors, smells, smoke, soot, heat, noise, vibrations and other similar impacts, if the This rule should be made as general as possible and should not be limited to landowners only. 


\section{Acknowledgements}

We are very grateful to Y.V. Blinova, a lecturer at the Altai State University Law Institute, who generously provided us with foreign English-language literature on the topic of the article, which helped to make the research more objective and in-depth. E.V. Shapovalova, a colleague at the institute and head of the legal service in the administration of Barnaul, provided us with very valuable statistics on the work of the city's administrative commissions. Thanks to her help, we were able to build our reasoning and conclusions on a solid foundation of reliable facts.

Director of the Institute A.A. Vasiliev and Head of the Department of Civil Law T.A. Filippova made every effort to organize our fruitful scientific activity in the midst of summer vacation, without them the article would not have been written. We should like to thanks to them.

\section{BIBLIOGRAPHIC REFERENCES}

About the statement of Sanitary norms $\quad 2.2 .4 / 2.1 .8 .562-96$. (1996). Noise on workplaces, in premises of inhabited, public buildings and in territory of inhabited building. The decision of the State Committee of Sanitary and Epidemiological Surveillance of the Russian Federation. Consultant Plus Reference System.

AltaiRegionalLegislativeAssembly. (2017).Availablefrom:http://www.akzs.ru/cache/6059-3a-537-2017sOprVSRFot04.10.17. pdf/ (Accessed on 06.08.2019).

Animal Housing and Protection in the Altai Territory. (2017). Law of Altai Krai. № 96- . Available from: http://docs.cntd. ru/document/450377806/ (Accessed on 06.08.2019).

Black's Law Dictionary. (2009). B. A. Garner. (Ed.). St. Paul: West Group.

Civil Code of Czech Republic. (2005). Ministry of Justice. Available from: http://obcanskyzakonik.justice.cz/images/pdf/CivilCode.pdf/

Civil Code of the Russian Federation. (2005). Consultant Plus Reference System.

Civil Code. (2008). Book 3: Patrimonial law: draft of the Supreme Editorial Commission for drafting the Civil Code (with explanations extracted from the works of the Editorial Commission). Moscow. Walters Klover.

Code of Administrative Offences of the Russian Federation. (2018). Consultant Plus Reference System.

Constitution of the Russian Federation. (1993). Consultant Plus Reference System.

Decision of the Supreme Court of the Russian Federation. (2008). Case 59-G08-12. Garant Reference System.

Decision of the Supreme Court of the Russian Federation. (2011a). Case 64-G11-36. Garant Reference System.

Decision of the Supreme Court of the Russian Federation. (2011b). Case 55-APG14-11. Garant Reference System.

Decision of Supreme Court of the Russian Federation. (2012a). Case 81-APG12-1. Garant Reference System.

Decision of the Supreme Court of the Russian Federation. (2012b). Case 46-APG12-14. Garant Reference System.

Decision of the Nagatinsky District Court of Moscow. (2014). Case 2-5163/2014.

Decision of the Supreme Court of the Russian Federation. (2015a). Case 74-APG15-15. Garant Reference System.

Decision of the Supreme Court of the Russian Federation. (2015b). Case 46-APG15-39. Garant Reference System.

Decision of the Sverdlovsk District Court. (2015c). Case 2-2309/2015. Available from: https://sudact.ru/regular/doc/ ZVvAG8SRKooH/ (Accessed 06.08.2019).

Decision of the Severouralsk City Court. (2016). Case 2-788/2016. Available from: https://sudact.ru/regular/doc/fpTacz6gnJdj/ (Accessed 06.08.2019).

Decision of the Leninsky District Court of Barnaul. (2017a). Case 12-100/17. Archive of the Leninsky District Court of Barnaul.

Decision of the Supreme Court of the Russian Federation. (2017b). Case 10-APG17-1. Garant Reference System.

Decision of the Altai Territory Court. (2017c). Case 3a-537/2017. Available from: http://www.akzs.ru/cache/6059-3a-5372017sOprVSRFot04.10.17.pdf/ (Accessed on 06.08.2019).

Decision of the Judicial Collegium for Administrative Cases of the Supreme Court of the Russian Federation. (2017d). Case 51-APG17-16. Available from: http://www.akzs.ru/cache/6059-3a-537-2017sOprVSRFot04.10.17.pdf/ (Accessed on 06.08.2019).

Decision of the Kalininsky District Court of Ufa, Republic of Bashkortostan. (2017e). Case 2-5744/2017. Garant Reference System.

Decision of the Mozhaisk City Court. (2017f). Case 2-1098/2017. Available from: https://jur24pro.ru/reshenie-sudov/208613/ (Accessed 06.08.2019).

Decision of the Leninsky District Court of Barnaul. (2019a). Case 12-123/2019. Archive of the Leninsky District Court of Barnaul.

Decision of the Leninskiy District Court of Barnaul. (2019b). Case 12-122/2019. Archive of the Leninskiy District Court of Barnaul. 
Decision of the Leninsky District Court of Barnaul. (2019c). Case 12-121/2019. Archive of the Leninsky District Court of Barnaul.

Decision of the Leninsky District Court of Barnaul. (2019d). Case 12-218/2019. Archive of the Leninsky District Court of Barnaul.

Decision of the Leninsky District Court of Barnaul. (2019e). Case 12-240/19. Archive of the Leninsky District Court of Barnaul.

Decision of the Tchaikovsky City Court of the Perm Territory. (2019f). Case 12-342/12. Garant Reference System.

Emelkina, I.A. (2016). Institute of Restriction of Property Rights in favor of neighbors (neighborhood law) in Russian law and in the law of certain European countries. Civil Law Herald, 2, 79-112.

Emelkina, I.A., Syubaeva, Y.D. (2017). Neighborhood law in civil law of Germany, Austria, Switzerland, France, USA: essence and regularities of development. Social and Political Sciences, 6, 70-73.

German Civil Code. (2008). Moscow. Walters Klover.

GOST R 56391-2015. (2015). National Standard of the Russian Federation. Services for non-productive animals. Housing of non-productive animals in urban conditions. General Requirements. Rosstandart order No. 268. Consultant Plus Reference System.

Hulsroj, P. (2006). To The Rescue, All Hands: The Good Neighbour Principle In International Law. (pp. 167-190). In J. Allain \& S. Mullally (Eds.). The Irish Yearbook of International: Volume 1. London: Hart Publishing. DOI: http://dx.doi. org/10.5040/9781472564269.ch-005

Human Rights Act. (1998). UK Legislation. Available from: http://www.legislation.gov.uk/ukpga/1998/42/enacted.

Hylton, K.N. (2015). Nuisance. Forthcoming in Encylopedia of Law and Economics. J. Backhaus (Ed.). Boston Univ. School of Law, Law and Economics Research Paper No. 14-60.

Kozlov, Y.M. (1999). Administrative law. Moscow. Lawyer.

Nolan, D. (2011a). A Tort Against Land: Private Nuisance as a Property Tort (pp. 459-490). D. Nolan and A. Robertson (Eds.). Rights and Private Law. Oxford. Hart Publishing.

Nolan, D. (2011b). Nuisance and Human Rights (pp. 165-194). In The Impact of the UK Human Rights Act on Private Law. David Hoffmann (Ed). Cambridge University Press.

Nolan, D. (2015). Nuisance, Planning and Regulation: The Limits of Statutory Authority (pp. 183-206). In Defences in Tort. Dyson, Goudkamp and Wilmot-Smith (Eds.). Oxford. Hart Publishing.

Novitskiy, I. (1924a). Neighborhood right (General limits of land plots use). Law and life. Books 7-8, 10-21.

Novitsky, I. (1924b). Neighborhood Law. Framework and meaning of the problem. Law and life. Book. 5-6, 3-12.

On administrative responsibility for committing offences in the territory of Altai Krai. (2002). Law of Altai Krai No. 46-ZS. Available from: http://docs.cntd.ru/document/940002330/ (Accessed on 06.08.2019).

On Amendments to Parts 1-4 of the Civil Code of the Russian Federation. (2019). Draft Federal Law 7538-6. Available from: http://docs.cntd.ru/document/902339437/ (Accessed on 06.08.2019).

On approval of SanPiN 2.1.2.2645-10. (2010). Sanitary-and-epidemiologic requirements to living conditions in residential buildings and premises. Resolution of the Chief State Sanitary Doctor of the Russian Federation. Consultant Plus Reference System.

On ensuring silence and peace of citizens in the Altai Territory. (2017). Law of Altai Krai 95- . Available from: http://docs. cntd.ru/document/450377807/ (Accessed on 06.08.2019).

On environmental protection. (2002). Federal Law 7-FZ. Consultant Plus Reference System.

On Responsible Treatment of Animals and Amendments to Certain Legislative Acts of the Russian Federation. (2018). Federal Law 498-FZ. Consultant Plus Reference System.

On Sanitary and Epidemiological Welfare of the Population. (1999). Federal Law 52-FZ. Consultant Plus Reference System.

Scott, S. (2017). Recent Developments in case law regarding neighbor law and its influence on the concept of ownership. Heinonline. Available from: https://heinonline.org/HOL/P?h=hein.journals/stelblr16\&i=445/

Shershenevich, G.F. (2001). Course of civil law. Tula. Autograph.

Squires, P. (2008). The criminalisation of nuisance. Policy Press.

The Max Planck encyclopedia of European private law. (2017). J. Basedow, K.J. Hopt, R. Zimmermann, A. Stier. (Eds.). Oxford: Oxford University Press.

Tikhomirov, Yu.A. (2001). Administrative law and process: full course. Moscow.

Tlesarev, S. (2016). Tilly-Tilly, Tilly-bom is a new cat's house. Housing law, 11, 43-52.

Van der Merve. (1998). For whom the bell tolls - a solution in neighbor law. Stellenbosch Law Review, 9, 35 